\title{
Clinical significance of rare serum autoantibodies in rheumatic diseases: a systematic literature review
}

\author{
Angela Ceribelli ${ }^{1,2}$, Natasa Isailovic ${ }^{1}$, Maria De Santis ${ }^{1}$, Elena Generali ${ }^{1}$, Carolina Gorlino ${ }^{1}$, Bianca \\ Palermo ${ }^{1}$, Carlo Selmi ${ }^{1,2}$ \\ ${ }^{1}$ Division of Rheumatology and Clinical Immunology, Laboratory of Autoimmunity and Metabolism, Humanitas Research Hospital, Milan, Italy; \\ ${ }^{2}$ BIOMETRA Department, University of Milan, Milan, Italy \\ Contributions: (I) Conception and design: A Ceribelli, C Selmi; (II) Administrative support: E Generali, B Palermo; (III) Provision of study material or \\ patients: A Ceribelli, M De Santis, C Selmi; (IV) Collection and assembly of data: E Generali, B Palermo, N Isailovic, C Gorlino; (V) Data analysis \\ and interpretation: E Generali, B Palermo, N Isailovic, C Gorlino; (VI) Manuscript writing: All authors; (VII) Final approval of manuscript: All \\ authors. \\ Correspondence to: Carlo Selmi, MD, PhD. Division of Rheumatology and Clinical Immunology, Humanitas Research Hospital, via A. Manzoni 56, \\ 20089 Rozzano, Milan, Italy. Email carlo.selmi@unimi.it.
}

\begin{abstract}
The identification of serum autoantibodies is central in the diagnosis of systemic autoimmune rheumatic disease (SARD), and an increasing number of specificities have been detected in the past years. This allows an early diagnosis in the active phases of diseases, with the identification of specific disease subsets that may ultimately improve the disease outcomes. Thanks to the use of old and new laboratory techniques that are becoming increasingly available worldwide, the number of rheumatic patients with a specific autoantibody is increasing and this is improving also our knowledge of disease trigger mechanisms. The paradigmatic example is the plethora of serum autoantibodies described in polymyositis and dermatomyositis, coined myositis-specific antibodies (MSA) which include antibodies directed against tRNA synthetases, anti-SRP, anti-Mi-2, and anti-TIF- $1 \gamma$ and can discriminate disease subtypes, particularly when associated with the risk of cancer. As a further example, anti-HMGCR antibodies have been reported in several studies in association with necrotizing autoimmune myositis that may follow statin use. To clarify the current knowledge on these rare specificities, we performed a systematic literature review. We focused on the main features associated to specific autoantibodies that are rarely identified in rheumatic disease, to increase the awareness and scientific knowledge on these autoantibodies in different ethnic groups worldwide.
\end{abstract}

Keywords: Immune tolerance; autoimmunity; systemic lupus erythematosus (SLE); systemic sclerosis (SSc); cancer

Received: 13 August 2018; Accepted: 25 September 2018; Published: 23 October 2018.

doi: $10.21037 /$ jlpm.2018.09.13

View this article at: http://dx.doi.org/10.21037/jlpm.2018.09.13

\section{Introduction}

Serum autoantibodies (autoAbs) represent the hallmark of systemic autoimmune rheumatic diseases (SARD) (1), and can be detected years before the development of clinical manifestations and diagnosis (2). Currently, a high number of autoAbs are routinely detected worldwide to assist the clinicians in the diagnosis of SARD and their importance is related to the fact that they correlate with disease phenotype and severity, independently from their frequency. However, some patients are still defined "seronegative" when no known or specific autoAb is detected (3).

Patients affected by SARD can develop various disease manifestations, which share in most cases serum ANA positivity, and they may be diagnosed as systemic sclerosis (SSc), systemic lupus erythematosus (SLE), Sjögren's syndrome $(\mathrm{SjS})$, polymyositis and dermatomyositis (PM/ $\mathrm{DM})$ and mixed connective tissue disease (MCTD). The 
clinical manifestations of SARD may also overlap in some cases (4), and the identification of serum autoAbs is of major importance not only for SARD diagnosis but also for their prognosis, as they may predict internal organ involvement and/or cancer coexistence, as for anti-TIF $1 \gamma / \alpha$ in inflammatory myositis associated with cancer (5). Moreover, anti-dsDNA and anti-Sm antibodies are classic serological markers of SLE, with increased titers of anti-dsDNA associated with a more active and severe disease such as lupus nephritis (6). Anti-topoisomerase I/Scl-70 and antiRNA polymerase I/III antibodies are both associated with diffuse scleroderma (dcSSc) with increased mortality rates due to interstitial lung disease (ILD) and renal crisis, while anti-centromere antibodies (ACA) are commonly detected in the limited cutaneous form of SSc (lcSSc), which may be related to the onset of pulmonary arterial hypertension (7).

Myositis-specific antibodies (MSA) include autoAbs directed against tRNA synthetases, anti-SRP, anti-Mi-2, and anti-TIF- $1 \gamma$. Among the anti-tRNA synthetases antibodies, anti-Jo-1 is the most frequently reported and this class of autoAbs is commonly associated with the occurrence of arthritis, myositis, ILD, Raynaud's phenomenon (RP), fever and mechanic's hands (8).

Recently, a novel ANA specificity defined by dense fine speckled (DFS) pattern has been reported but it is now considered the most frequent ANA pattern in healthy individuals, thus it may have a protective role towards the development of SARD (9).

As described, the identification of a specific autoAb is important to define the diagnosis and the prognosis of specific SARDs such as SLE and SSc. However, the diagnosis of SARD might be challenging when clinical manifestations are weak, heterogeneous and uncommon, and in those patients without detectable autoAb, therefore patients do not fulfill classification criteria (10-13). The identification of rare or non-diagnostic serum autoAbs might be challenging as well and in most cases the search for these autoAbs cannot be performed routinely but only by research laboratories in a few centers worldwide. Furthermore, novel rare autoAbs with unknown clinical associations are detected in a small number of patients with CTD, and only few observational studies have addressed these infrequent serological markers and published data that mostly derive from single case reports. Therefore, the diagnostic and prognostic value of these markers, as well as their potential role in monitoring disease activity and predicting specific organ involvement, still remains unknown.

\section{Systematic literature review for the identification of rare autoAbs in rheumatic diseases}

Based on the principles described above, we conducted a systematic literature review to identify the prevalence and clinical significance of rare autoAbs in SARD. The systematic review procedures we adopted are in line with the Preferred Reporting Items for Systematic Reviews and Meta-Analyses (PRISMA) guidelines (14). The structured literature research was conducted as of January $20^{\text {th }} 2017$ in the following databases: The Cochrane Library, PubMed/ MEDLINE and EMBASE. Search terms included the medical subject headings (MeSH) or Emtree terms for "systemic sclerosis", "systemic lupus erythematosus", "sjögren’s syndrome", "dermatomyositis", "polymyositis", "mixed connective tissue disease", "connective tissue disease", "anti-synthetase syndrome", "autoantibodies", "rare", "prevalence", and "clinical significance". Titles and abstracts were screened to determine if they met the inclusion criteria and if they were of potential interest, then two independent reviewers (Bianca Palermo and Elena Generali) selected relevant abstracts. Articles of seminal importance were included in the final analysis.

\section{Inclusion criteria}

Observational studies, case reports and clinical trials were included.

\section{Exclusion criteria}

Articles not concerning SARD, and reviews or editorials in languages different from English, if including children or animals, were excluded to limit the literature review to adults and because no funding was available for translation. The selection process was performed by two authors, based on titles, abstracts and subsequently full text papers. Figure 1 represents the flowchart of the selection process of this systematic literature review.

\section{Data extraction}

The year of publication, study design, number of patients and demographic data were recorded. The outcome was defined by the identification of rare autoAbs and their prevalence and clinical significance in SARD. Articles were divided into categories depending on the disease. 


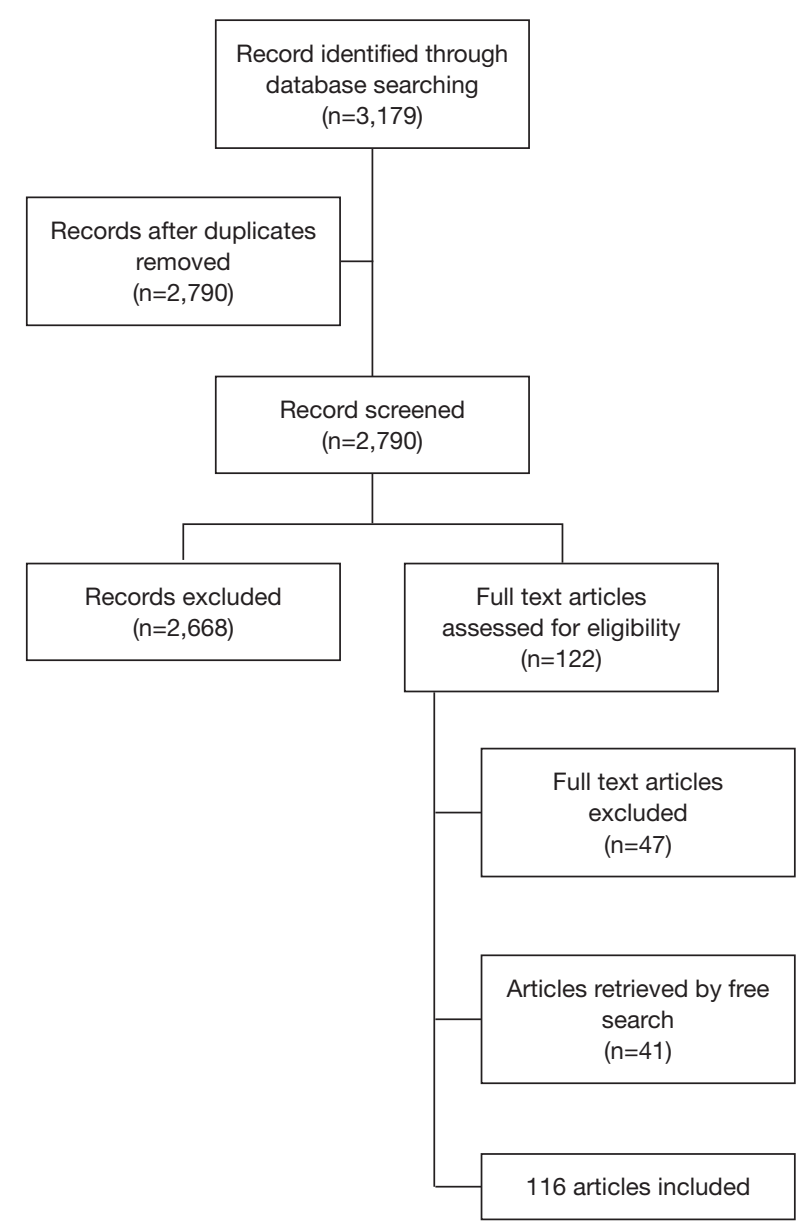

Figure 1 Flowchart of the articles selection process reporting autoAbs in SARD, then described in the present review.

\section{Results of the systematic literature review}

The literature search allowed us to identify articles $(n=116)$ that are described in the Tables below, that show the prevalence and clinical significance of autoAbs in each specific SARD.

\section{AutoAbs in SLE}

SLE is a chronic systemic autoimmune disease characterized by the positivity of specific autoAbs, namely anti-dsDNA and anti-Sm, but several other rare autoAbs have been reported in association with SLE as described in Table 1. The appearance of the autoAbs in SLE has been demonstrated to start years before the clinical onset of the disease, thus autoAbs in SLE patients have are fundamental for early diagnosis and treatment (2).
Among the rare autoAbs identified in SLE patients, antiRNP antibodies are frequently detected in SLE patients $(15,19,20,22-26,28-30)$ with a prevalence ranging from $9.5 \%$ to $30 \%(15,19,20,22,24,31)$. They have been reported in association with neuropsychiatric SLE (NPSLE), and in case reports in association with anti-CASPR2 antibodies (32), shrinking lung syndrome (30) and Crohn's disease (28). Anti-Ku antibodies have been detected in the sera of 18 (11.6\%) African American SLE patients, while they were not found in SLE Caucasian patient $(25,33)$. Anti-NKG2A antibodies have been detected in one patient with SLE, in particular in association with vascular involvement and deep venous thrombosis, renal involvement, progressive alveolitis and increased levels of interferon $\alpha$ (17). Anti-replication protein A antibodies (anti-RPA) have been found in 1.4\% of SLE patients (and in $2.5 \%$ of $\mathrm{SjS}$ patients), with a subset of SLE without other autoAbs commonly found in SLE (27). Very high titers of antibodies to glucose-6-phosphate isomerase (anti-GPI) were reported in one patient with SLE with articular involvement (21). Anti-neuronal antibodies are being evaluated in NPSLE, i.e., anti-VGCK, CASPR2, NMDA-R, LGI1, GAD, AMA-R, GABA $-\mathrm{R}$ antibodies; however, Karaaslan et al. found that, in a cohort of eighteen SLE patients with epilepsy, only one female patient had anti-GAD, one female patient with hippocampal sclerosis on magnetic resonance imaging was CASPR-2 antibody positive, whereas four female patients showed hippocampal neutrophil staining reflecting antibodies against unknown neuronal cell surface antigens (18). One case of anti-VGKC positive antibodies in a SLE patient followed by acquired neuromyotonia development was reported (29). Another autoAb described in SLE patients is represented by antiGW182 autoAbs that have been detected in SLE and SjS patients, mostly female, and interestingly, six patients manifested neurological disease (16).

\section{AutoAbs in SSc}

Serological markers of SSc are shown in Table 2. AutoAbs to nucleolar antigens (ANoA) have been reported to occur in $8-47 \%$ of sera from patients with SSc $(41,43,52)$, and they include PM-Scl (57), RNA polymerase I (41), Th/To $(43,57,58)$, and small nucleolar RNP particles, such as U3 RNP/fibrillarin (51,52).

The prevalence of anti-U3 RNP/fibrillarin antibodies ranges between $1.1-18 \%$ in SSc patients, who are more likely to be African American male patients with dcSSc and younger age at disease onset $(35,36,43,46,47,51-53$, 
Table 1 Prevalence and clinical significance of rare serum autoAbs in systemic lupus erythematosus (SLE)

\begin{tabular}{|c|c|c|c|c|c|c|c|}
\hline Study & Year & Disease & $\begin{array}{l}\text { Study } \\
\text { design }\end{array}$ & $\begin{array}{l}\text { Number of cases/ } \\
\text { controls }\end{array}$ & Autoantibody & Methods & Main clinical associations \\
\hline Black (15) & 2002 & $\begin{array}{l}\text { SLE }(12.5 \%) \\
\text { and SCLE } \\
(1.3 \%)\end{array}$ & $\begin{array}{l}\text { Case- } \\
\text { control }\end{array}$ & $24 / 76$ & Anti-U1RNP & $\begin{array}{l}\text { Review of } \\
\text { medical } \\
\text { records }\end{array}$ & $\begin{array}{l}\text { More prevalent in SLE than SCLE } \\
\text { patients }\end{array}$ \\
\hline $\begin{array}{l}\text { Eystathioy } \\
\text { (16) }\end{array}$ & 2003 & SLE, SjS & Cohort & 200 & Anti-GW182 & $\begin{array}{l}\text { Laser bead } \\
\text { IF }\end{array}$ & $\begin{array}{l}\text { Eighteen subjects, mostly women } \\
(17,94.4 \%), 4 \text { with SLE and } 5 \text { with } \\
\text { SjS; } 6 \text { patients had neurological } \\
\text { disease }\end{array}$ \\
\hline $\begin{array}{l}\text { Hagberg } \\
\text { (17) }\end{array}$ & 2013 & SLE & $\begin{array}{l}\text { Case- } \\
\text { control }\end{array}$ & $\begin{array}{l}\text { SLE [94]; SjS [60]; } \\
\mathrm{HC}[30]\end{array}$ & Anti-NKG2A & $\begin{array}{l}\text { Flow } \\
\text { cytometry }\end{array}$ & $\begin{array}{l}\text { Vasculitis, skin rashes, renal } \\
\text { involvement, and progressive } \\
\text { alveolitis in } 1 \text { patient with increased } \\
\text { levels of IFN- } \alpha \text {; anti-Sm and anti- } \\
\text { RNP were also present }\end{array}$ \\
\hline Lee (19) & 2002 & SLE & Cohort & 175 & Anti-RNP & $N / A$ & Lupus enteritis \\
\hline $\operatorname{Lin}(20)$ & 2012 & $\begin{array}{l}\text { Late-onset } \\
\text { SLE }(\geq 50 \\
\text { years })\end{array}$ & Cohort & 158 & $\begin{array}{l}\text { Anti-U1RNP; } \\
\text { Anti-RibP }\end{array}$ & $\begin{array}{l}\text { IIF (Hep- } \\
\text { 2), Crithidia } \\
\text { luciliae }\end{array}$ & $\begin{array}{l}\text { Hematological }(61.4 \%) \text {, renal } \\
(57.0 \%) \text { and articular }(53.2 \%) \\
\text { involvement most common, CNS } \\
\text { affection was rare }(3.2 \%)\end{array}$ \\
\hline $\begin{array}{l}\text { Matsumoto } \\
(21)\end{array}$ & 2003 & SARD & $\begin{array}{l}\text { Case- } \\
\text { control }\end{array}$ & $\begin{array}{l}578 \text { (RA 291, PsA 20, } \\
\text { JRA 4, SpA 46, UA, } \\
\text { 80, arthralgia 16, viral } \\
\text { arthritis 3, SLE 38, } \\
\text { SjS 20, sarcoidosis } \\
\text { 20, CD 40); } 136 \text { HC }\end{array}$ & $\begin{array}{l}\text { Anti-glucose- } \\
6 \text {-phosphate } \\
\text { isomerase (anti- } \\
\text { GPI) }\end{array}$ & $\begin{array}{l}\text { ELISA with } \\
\text { recombinant } \\
\text { and native } \\
\text { GPI, IB }\end{array}$ & $\begin{array}{l}\text { Very high titers were found in } \\
1 \text { SLE, } 1 \text { seronegative RA, and } \\
1 \text { RA with severe extraarticular } \\
\text { manifestations }\end{array}$ \\
\hline $\mathrm{Su}(23)$ & 2014 & SLE with LN & Cohort & 559 & $\begin{array}{l}\text { Anti-RNP } \\
\text { Anti-Jo-1 }\end{array}$ & N/A & $\begin{array}{l}\text { Numbness and functional } \\
\text { gastrointestinal problems were the } \\
\text { most common symptoms. Only } \\
\text { anti-Ro/SSA was independently } \\
\text { associated with peripheral } \\
\text { neuropathy in SLE-LN patients }\end{array}$ \\
\hline $\begin{array}{l}\text { Van Venrooij } \\
\text { (24) }\end{array}$ & 1990 & SLE & Cohort & 118 & Anti-U1snRNA & $\begin{array}{l}\text { CIE, RNA-IP, } \\
\text { IB }\end{array}$ & SLE or SLE overlap syndromes \\
\hline Wang (25) & 2001 & SLE & Cohort & $\begin{array}{l}\text { African American } \\
\text { [155]; Caucasian } \\
\text { [126] }\end{array}$ & $\begin{array}{l}\text { Anti-Ku; Anti- } \\
\text { nRNP }\end{array}$ & IP & $\begin{array}{l}\text { Anti-Ku were detected in sera } \\
\text { from } 18 / 155 \text { African American } \\
\text { patients with SLE (12\%) vs. 0/126 } \\
\text { Caucasian patients. Anti-nRNP } \\
\text { ( } 63 \% \text { vs. } 16 \%) \text { and anti-Sm }(23 \% \\
\text { vs. } 7 \%) \text { were also more common in } \\
\text { African American patients }\end{array}$ \\
\hline
\end{tabular}

Table 1 (continued) 
Table 1 (continued)

\begin{tabular}{|c|c|c|c|c|c|c|c|}
\hline Study & Year & Disease & $\begin{array}{l}\text { Study } \\
\text { design }\end{array}$ & $\begin{array}{l}\text { Number of cases/ } \\
\text { controls }\end{array}$ & Autoantibody & Methods & Main clinical associations \\
\hline Xi (26) & 2016 & $\begin{array}{l}\text { SjS, SLE, } \\
\text { RA, UCTD, } \\
\text { DM }\end{array}$ & Cohort & 180 & $\begin{array}{l}\text { Anti-MSA; Anti- } \\
\text { RNP }\end{array}$ & IIF and IB & $\begin{array}{l}\text { The most frequent clinical } \\
\text { symptoms in anti-MSA (+) patients } \\
\text { were arthralgia (35.7\%) and sicca } \\
(28.5 \%)\end{array}$ \\
\hline $\begin{array}{l}\text { Yamasaki } \\
(27)\end{array}$ & 2006 & $\begin{array}{l}\text { SLE, PM/ } \\
\text { DM, SjS, } \\
\text { SSc, RA }\end{array}$ & Cohort & $\begin{array}{l}1,119 \text { (276 SLE, } 43 \\
\text { PM/DM, } 47 \text { SSc, } 40 \\
\text { SjS, } 35 \text { RA) }\end{array}$ & Anti-RPA & $\begin{array}{l}\text { IP, ELISA, IIF, } \\
\text { WB }\end{array}$ & $\begin{array}{l}\text { Anti-RPA-positive patients may } \\
\text { form a unique group of SLE } \\
\text { patients (interstitial lung disease, } \\
\text { autoimmune thyroiditis/hepatitis C } \\
\text { virus/pernicious anemia) without } \\
\text { other autoantibodies commonly } \\
\text { found in SLE }\end{array}$ \\
\hline
\end{tabular}

DM, dermatomyositis; ELISA, enzyme linked immunosorbent assay; IB, immunoblotting; IIF, indirect immunofluorescence; IP, immunoprecipitation; LN, lupus nephritis; MSA, mitotic spindle apparatus; N/A, not available; NPSLE, neuropsychiatric lupus; PM/DM, polymyositis/dermatomyositis; RA, rheumatoid arthritis; RIA, radioimmunoassay; RPA, replication protein A; SCLE, subacute cutaneous lupus erythematosus; SjS, Sjögren's syndrome; SLE, systemic lupus erythematosus; SSc, systemic sclerosis; UCTD, undifferentiated connective tissue disease; WB, western blot.

56,59,60). In contrast, Tormey et al. found a high proportion of Caucasian patients with lcSSc and anti-U3 RNP/fibrillarin positivity (61). In additional reports, anti-U3 RNP/fibrillarin antibodies are associated with higher prevalence of hypo/hyper- skin pigmentation (51,53), calcinosis (51), digital pitting scars and/or ulcers $(51,53)$, digital amputation (62), myositis $(47,51,60,61)$, PAH $(51,53,61)$, pulmonary fibrosis $(35,46,52,61)$, diarrhea and gastric antral vascular ectasia (GAVE) $(59,62)$, cardiac and renal involvement $(35,59,61)$. Arnett et al. found a significant association between anti-U3 RNP/fibrillarin and the HLA class II haplotype DRB1*1302, DQB1*0604; in addition, one or more HLA-DQB1 alleles *0604, *0301, *0602, and/or *0302 were detected in all anti-U3 RNP/ fibrillarin positive patients who joined the study (35). Furthermore, anti-U3 RNP/fibrillarin may be more frequently related to the rare occurrence of SSc/ANCAassociated vasculitis (AAV) than the other sclerodermaspecific antibodies. Glomerulonephritis, renal arteritis, and pulmonary fibrosis occur more frequently than expected in SSc/AAV overlap (38), and a case of nodular scleroderma with positive anti-U3RNP/fibrillarin antibodies has been reported $(63,64)$.

Anti-RNA polymerase (RNApol) antibodies are directed towards the antigens called RNA polymerase I-III, and antiRNApolIII antibodies are the most relevant as they have been recently included in the SSc classification criteria (65). Their identification has been possible in the past thanks to a time and labor consuming technique called "immunoprecipitation" until the late 90's when a specific RNAP ELISA was developed and validated as described by Chang et al. (33). This allowed the large scale and rapid identification of anti-RNApol antibodies in a clinical diagnostic laboratory setting to identify SSc patients who are at risk for developing SSc with these autoAbs $(66,67)$. Anti-RNApol antibodies are found in $1.1 \%$ to $15 \%$ of SSc patients $(33,36,37,40,41,45,47,49,52,54,68)$ and antiRNA polymerase I/III positive patients are more likely to develop dcSSc with pulmonary involvement, joint and tendon involvement, myositis, and a significantly increased risk of scleroderma renal crisis $(33,37,40,45,47,49,50,52,62)$. However, patients with anti-RNA polymerase III antibodies have lower risk of gastrointestinal (GI) manifestations and esophageal dysmotility compared to patients with anti-topo $\mathrm{I} / \mathrm{Scl} 70(40,62)$, as well as a lower incidence of pulmonary disease (40). A subset of anti-RNA polymerase III positive patients may have an atypical clinical presentation with the onset of scleroderma prior to Raynaud's phenomenon (36). In 2010, Shah et al. (69) first reported a possible association of anti-RNA polymerase I/III with the development of malignancy that occurred concomitantly to SSc onset in a small number of US patients. Subsequently, the higher frequency of synchronous cancer cases in SSc patients with anti-RNA polymerase III antibodies has been validated in independent SSc patients of European, Australian and Japanese populations $(34,48,50,54)$.

Autoantibodies to U1RNP are commonly detected in scleroderma overlap syndromes, with frequency ranging 
Table 2 Prevalence and clinical significance of rare serum autoAbs in systemic sclerosis (SSc)

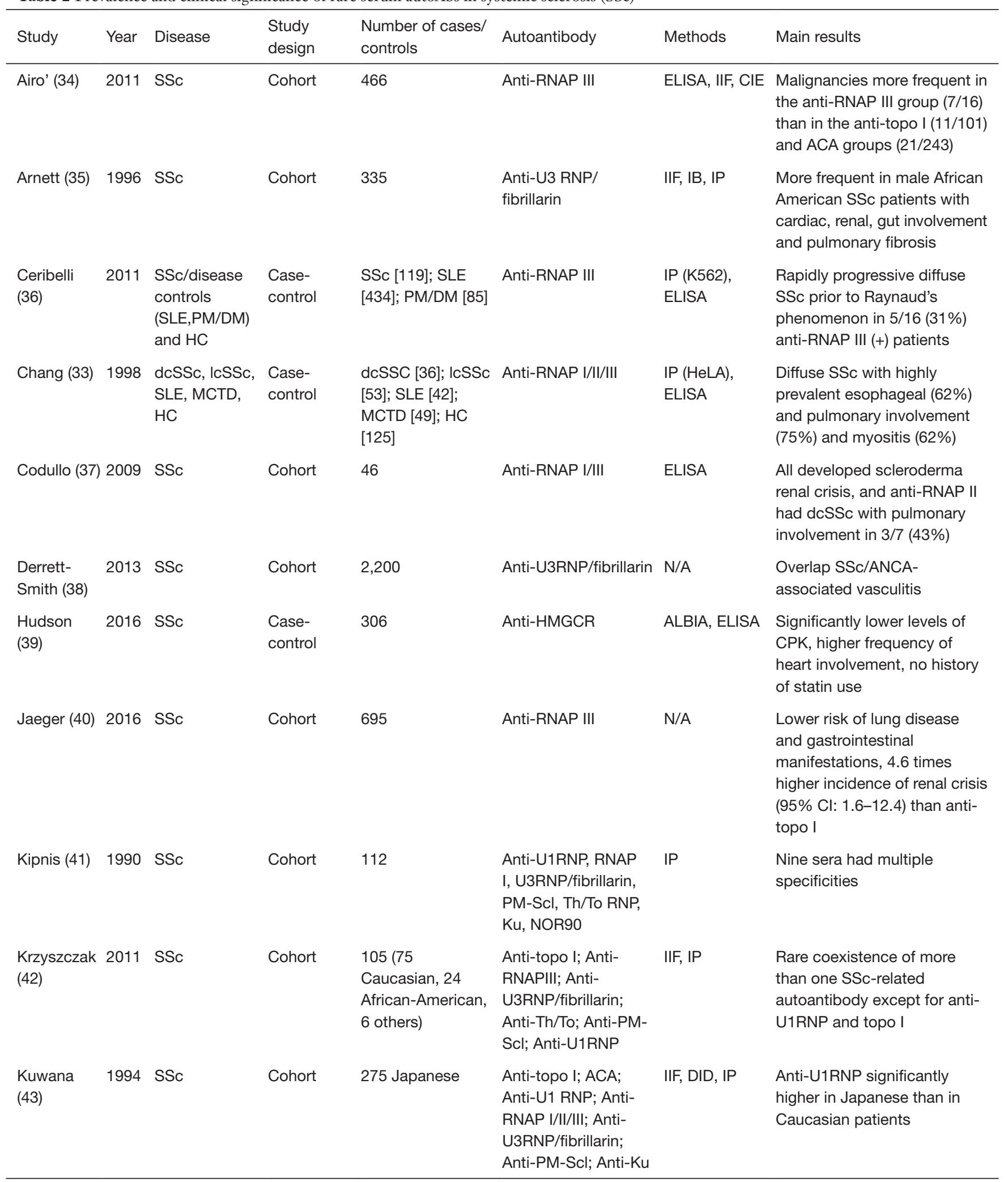

Table 2 (continued) 
Table 2 (continued)

\begin{tabular}{|c|c|c|c|c|c|c|c|}
\hline Study & Year & Disease & $\begin{array}{l}\text { Study } \\
\text { design }\end{array}$ & $\begin{array}{l}\text { Number of cases/ } \\
\text { controls }\end{array}$ & Autoantibody & Methods & Main results \\
\hline Lega (44) & 2010 & $\begin{array}{l}\text { PM/DM, } \\
\text { UCTD, ISSc, } \\
\text { amyopathic } \\
\text { DM, } \\
\text { amyopathic } \\
\text { DM/SjS/SSc } \\
\text { overlap }\end{array}$ & Cohort & $\begin{array}{l}9 \text { anti-PM-Scl, } 12 \\
\text { anti-ARS (7 anti- } \\
\text { Jo1, } 3 \text { anti-PL7, } 1 \\
\text { anti-EJ, } 1 \text { double- } \\
\text { positive for anti- } \\
\text { EJ and anti-OJ), } 1 \\
\text { anti-PM-Scl and } \\
\text { anti-ARS }\end{array}$ & $\begin{array}{l}\text { Anti-PM-Scl; Anti- } \\
\text { ARS }\end{array}$ & ELISA, IP & $\begin{array}{l}\text { Prevalence of respiratory } \\
\text { symptoms, pulmonary } \\
\text { function test results and } \\
\text { HRCT patterns did not } \\
\text { significantly differ }\end{array}$ \\
\hline Maes (45) & 2010 & $\begin{array}{l}\text { SSc, PM/ } \\
\text { DM, SLE, SjS, } \\
\text { RA, MCTD, } \\
\text { chronic fatigue } \\
\text { syndrome and } \\
\text { HC }\end{array}$ & $\begin{array}{l}\text { Prevalence } \\
\text { case- } \\
\text { control }\end{array}$ & $\begin{array}{l}242 \text { (70 SSc, } 13 \\
\text { PM, } 23 \text { DM, } 66 \\
\text { SLE, } 35 \text { SjS, } 24 \\
\text { RA, } 11 \text { MCTD). } \\
36 \text { controls ( } 9 \text { HC, } \\
27 \text { chronic fatigue } \\
\text { syndrome) }\end{array}$ & $\begin{array}{l}\text { Anti-PM-Scl 100; } \\
\text { Anti-RNAPIII }\end{array}$ & $\begin{array}{l}\text { ELISA, IIF, dot } \\
\text { blot }\end{array}$ & $\begin{array}{l}\text { At high levels, anti-PM-Scl100 } \\
\text { were exclusively found in SSc } \\
(4.3 \%) \text {, DM }(4.3 \%) \text { and PM } \\
(6.1 \%)\end{array}$ \\
\hline $\begin{array}{l}\text { McNearney } \\
\text { (46) }\end{array}$ & 2007 & SSc & Cohort & $\begin{array}{l}203 \text { (104 Whites, } \\
39 \text { African } \\
\text { Americans, } 60 \\
\text { Hispanics) }\end{array}$ & $\begin{array}{l}\text { Anti-U3RNP/ } \\
\text { fibrillarin; Anti-RNP }\end{array}$ & IIF, ID, IP & $\begin{array}{l}\text { Factors independently } \\
\text { associated with early } \\
\text { pulmonary involvement } \\
\text { included African American } \\
\text { ethnicity, skin score, serum } \\
\text { creatinine and CPK levels, } \\
\text { hypothyroidism and cardiac } \\
\text { involvement. }\end{array}$ \\
\hline Mierau (47) & 2011 & SSc & Cohort & $\begin{array}{l}863 \text { (IcSSc 513, } \\
\text { dcSSc } 173, \\
\text { scleroderma } \\
\text { overlap syndrome } \\
\text { 108, UCTD with } \\
\text { scleroderma } \\
64, \text { SS sine } \\
\text { scleroderma 5) }\end{array}$ & $\begin{array}{l}\text { Anti-U1RNP; Anti- } \\
\text { PM-Scl; Anti-M2; } \\
\text { Anti-RNAP I/II; Anti- } \\
\text { Ku; Anti-U3RNP/ } \\
\text { fibrillarin; Anti-Th/To; } \\
\text { Anti-NOR-90; Anti- } \\
\text { ARS; Anti-p25/p23 }\end{array}$ & $\begin{array}{l}\text { IIF, line } \\
\text { immunoassay, } \\
\text { IP, ID }\end{array}$ & $\begin{array}{l}\text { Anti-p25/p23 characterise } \\
\text { a subset within the ACA + } \\
\text { group strongly associated } \\
\text { with SSc }(71.4 \%)\end{array}$ \\
\hline Motegi (49) & 2015 & SSc & Cohort & 246 & Anti-RNAP III & ELISA & $\begin{array}{l}\text { High skin score and risk of } \\
\text { renal crisis }\end{array}$ \\
\hline $\begin{array}{l}\text { Nikpour } \\
(50)\end{array}$ & 2015 & SSc & Cohort & 451 & Anti-RNAPIII & ELISA & $\begin{array}{l}\text { Independently associated } \\
\text { with renal crisis (OR 3.8), } \\
\text { diffuse disease (OR 6.4), joint } \\
\text { contractures (OR } 2.5 \text { ) and } \\
\text { malignancy diagnosed within } \\
5 \text { years of onset of SSc skin } \\
\text { disease (OR 4.2) }\end{array}$ \\
\hline
\end{tabular}

Table 2 (continued) 
Table 2 (continued)

\begin{tabular}{|c|c|c|c|c|c|c|c|}
\hline Study & Year & Disease & $\begin{array}{l}\text { Study } \\
\text { design }\end{array}$ & $\begin{array}{l}\text { Number of cases/ } \\
\text { controls }\end{array}$ & Autoantibody & Methods & Main results \\
\hline Okano (51) & 1992 & SSc & $\begin{array}{l}\text { Case- } \\
\text { control }\end{array}$ & $\begin{array}{l}416 \text { cases; } 264 \\
\text { controls }\end{array}$ & Anti-U3RNP/fibrillarin & IIF, IP & $\begin{array}{l}\text { More frequent in African } \\
\text { American patients with dcSSc }\end{array}$ \\
\hline Okano (31) & 1996 & $\begin{array}{l}\text { SSc, PM/DM, } \\
\text { SLE, overlap } \\
\text { syndromes, } \\
\text { SjS }\end{array}$ & Cohort & $\begin{array}{l}1,171 \text { (SSc } \\
548, \text { PM/DM } \\
\text { 193, overlap } \\
\text { syndromes } 164, \\
\text { SLE 194, SjS 72) }\end{array}$ & Anti-U5snRNP & IP, IIF, IB & $\begin{array}{l}\text { Identified in a patient with } \\
\text { SSc/PM overlap syndrome } \\
\text { and with RP, sclerodactyly, } \\
\text { puffy fingers, esophageal } \\
\text { hypomotility and inflammatory } \\
\text { myopathy }\end{array}$ \\
\hline Reimer (52) & 1988 & SSc & Cohort & 646 & $\begin{array}{l}\text { Anti-RNAP I; Anti- } \\
\text { U3RNP/fibrillarin; } \\
\text { Anti-PM-Scl }\end{array}$ & IIF, IB, IP & $\begin{array}{l}\text { Anti-RNAP I were associated } \\
\text { with dcSSc of short duration, } \\
\text { joint and tendon involvement, } \\
\text { higher prevalence of renal } \\
\text { crisis }\end{array}$ \\
\hline $\begin{array}{l}\text { Saigusa } \\
(54)\end{array}$ & 2015 & SSc & Cohort & 261 & Anti-RNAP III & ELISA & $\begin{array}{l}\text { The prevalence of malignancy } \\
\text { was significantly higher in } \\
\text { patients with anti-RNAP III } \\
(7 / 22,31.8 \%) \text { than in those } \\
\text { with anti-topo I }(2 / 82,2.4 \%) \\
\text { and ACA }(8 / 137,5.8 \%)\end{array}$ \\
\hline Yang (56) & 2003 & SSc & Cohort & $\begin{array}{l}220 \text { (59 } \mathrm{ANoA}+ \\
161 \text { ANoA-) }\end{array}$ & $\begin{array}{l}\text { Anti-hU3-55K; Anti- } \\
\text { U3RNP/fibrillarin; } \\
\text { Anti-Mpp10 }\end{array}$ & IIF, IB, IP & $\begin{array}{l}\text { The } 74 \%(23 / 31) \text { of the anti- } \\
\text { U3RNP/fibrillarin + sera also } \\
\text { had anti-Mpp10, but only } \\
\text { 32\% (10/31) were positive for } \\
\text { anti-hU3-55K }\end{array}$ \\
\hline
\end{tabular}

ACA, anti-centromere antibodies; ANoA, antinucleolar autoantibodies; ARS, aminoacyl-tRNA synthetases; CIE, counterimmunoelectrophoresis; DID, double immunodiffusion; ELISA, enzyme-linked immunosorbent assay; dcSSc, diffuse cutaneous systemic sclerosis; HC, healthy controls; IB, immunoblotting; IIF indirect immunofluorescence; IIM, idiopathic inflammatory myopathy; IP, immunoprecipitation; IcSSc, limited cutaneous systemic sclerosis; MCTD, mixed connective tissue disease; N/A, not available; OR, odds ratio; PM/DM, polymyositis/dermatomyositis; PsA, psoriatic arthritis; RA, rheumatoid arthritis; RNAP, RNA polymerase; RP, Raynaud's phenomenon; SjS, Sjögren's syndrome; SLE, systemic lupus erythematosus; SpA, spondyloarthritis; SSc, systemic sclerosis; UCTD, undifferentiated connective tissue disease. 
from $4.8 \%$ to $10.7 \%$ in SSc patients $(41,47)$. Specific autoantibodies to U5snRNP represent a rare finding $(2.4 \%)$ in patients with SSc-PM overlap syndrome (31). Anti-Ku and anti-PM-Scl antibodies, when found in SSc patients (about $1.2-1.8 \%$ and $4.0-4.9 \%$, respectively), are often related to overlap syndromes with muscular manifestations, including creatine phosphokinase (CPK) elevation (45). Antibodies to p25/p23 characterize a subset within the ACA-positive SSc patients, which is strongly associated with SjS symptoms (47). A case report of nephrotic syndrome in a patient with $1 \mathrm{cSS} c$ and anti-ribosomal $\mathrm{P}$ antibodies was found (70). The association of anti-HMGCR antibodies and necrotizing autoimmune myositis (NAM) is wellknown (71,72). Such autoAbs have been identified in $1.3 \%$ of SSc patients; these subjects show significantly lower levels of CPK, a higher frequency of heart involvement and pulmonary hypertension, and no history of statin use (39).

A DFS pattern at IIF and anti-DSF70 antibodies have been reported to be less frequent in SSc patients than healthy controls (73-76).

\section{AutoAbs in polymyositis/dermatomyositis (PM/DM) and in the anti-synthetase syndrome}

As described in the results shown in Table 3, anti-synthetase antibodies identified in myositis patients have a variable prevalence, and this depends on each single specificity. In particular, anti-Jo-1 antibodies have the highest prevalence ranging from $0.5 \%$ to $54.7 \%(82,88)$, while other antisynthetase antibodies have lower prevalence, as for antiPL-7 0.5-9.3\% (82,90), anti-PL-12 1.5-19.2\% (82,88), anti-OJ $0.5 \%(82,88)$, anti-EJ $1-3 \%(82,88)$. Antibodies to asparaginyl-tRNA synthetase (anti-KS) occur in $0.3-0.5 \%$ of patients with CTD-especially in Japanese patients $(62.5 \%)$ - most of them presenting ILD (88\%)—while an association with myositis was rarely found, as it was detected in $0 \%$ of Japanese subjects with PM/DM and in 25\% of all positive patients. Interestingly, cancer history was reported in $25 \%$ of anti-KS positive patients (83), thus it may be very important to be able to identify this rare autoAb not only for diagnostic but also for prognostic evaluations. With regard to clinical manifestations, overall anti-synthetase antibodies are more frequent in female patients with diffuse cutaneous involvement similarly to limited SSc, arthralgia, joint deformities, high CK levels (88), and overlap myositis (90). Lung involvement is a common manifestation of antisynthetase syndrome, and anti-Jo-1 antibodies have been reported in association with ILD $(91,92)$, even though a larger study reported that anti-Jo-1 (+) patients have higher rates of myositis and arthralgia than ILD, as well as higher CK levels compared to anti-PL-12 and PL-7 (+) patients (81). Anti-synthetase antibodies have also been detected in a case of cryptogenic organizing pneumonia (93) and in association with uncommon clinical manifestations such as aphthous-like ulcerations and xerostomia (94). As for their prognostic significance, anti-PL-12 and PL-7 antibodies are related to lower survival rates $(81,82)$, and anti-EJ antibodies have been reported in a case of fatal myocarditis in anti-synthetase syndrome (95).

Rare autoAbs reported in PM/DM patients include antiMi-2 (5\%) 90), anti-SRP (2.8\%) (90), anti-Ku (1-1.7\%) $(90,96)$ and anti-HMGCR $(3 \%)(96,97)$. In particular, antiMi-2 and anti-SRP antibodies are more common in female patients affected by DM, while DM skin manifestations are less frequently seen in anti-Ku and anti-SRP positive patients. Anti-SRP antibodies have been associated with higher CK levels (90) in clinically relevant myositis (86), and more severe clinical symptoms, such as rapidly developing muscle weakness and atrophy, dysphagia, ILD complicated by massive pleural effusion and respiratory insufficiency (89,98-100) with poor response to immunosuppressive treatments (101).

Anti-HMGCR antibodies have been reported in several studies $(77,78,102-106)$, in particular in association with necrotizing autoimmune myositis (NAM) (44.9\%), followed by PM (4.4\%) and DM (1.9\%) (107). The titer of anti-HMGCR antibodies seems to correlate with CPK levels (106) and their association with statin therapy is controversial since some studies report that less than $50 \%$ of patient have used statins $(77,80,97,105)$, while other reports suggest a strong association in a higher percentage of cases $(89,104,107,108)$. A case of NAM associated with anti-HMGCR antibodies with severe head and neck involvement, resembling a retropharyngeal abscess, has also been reported (71).

As for anti-TIF1 $\gamma$ antibodies, they have been detected mainly in cases of paraneoplastic myositis associated in particular with solid tumors such as breast cancer (109), thus they have not only a diagnostic but also a prognostic value for myositis patients.

When histology is considered, anti-Mi-2 and antisynthetase antibodies are more frequent in cases with typical DM involvement, while unspecified myositis is the most frequent pathologic finding in patients with anti$\mathrm{Ku}$ antibodies, and NAM is present in $75 \%$ of anti-SRP positive subjects (90). 
Table 3 Prevalence and clinical significance of rare serum autoAbs in polymyositis/dermatomyositis (PM/DM) and anti-synthetase syndrome

\begin{tabular}{|c|c|c|c|c|c|c|c|}
\hline Study & Year & Disease & $\begin{array}{l}\text { Study } \\
\text { design }\end{array}$ & $\begin{array}{l}\text { Number of cases/ } \\
\text { controls }\end{array}$ & Autoantibody & Methods & Main results \\
\hline $\begin{array}{l}\text { Allenbach } \\
\text { (77) }\end{array}$ & 2014 & $\begin{array}{l}\text { Necrotizing } \\
\text { myopathy }\end{array}$ & Cohort & 206 & Anti-HMGCR & ALBIA & $\begin{array}{l}\text { Statin exposure was present in } \\
44.4 \% \text { [20] of patients }\end{array}$ \\
\hline $\begin{array}{l}\text { Alvarado- } \\
\text { Cardenas } \\
(78)\end{array}$ & 2016 & $\begin{array}{l}\text { Statin- } \\
\text { associated } \\
\text { autoimmune } \\
\text { myopathy }\end{array}$ & Cohort & 23/135 & Anti-HMGCR & ELISA & $\begin{array}{l}23 \text { cases, } 14 \text { (82\%) were } \\
\text { exposed to statins, } 15 \text { ( } 88 \%) \text { had } \\
\text { IMNM at muscle biopsy }\end{array}$ \\
\hline Coppo (79) & 2002 & Myositis & Cohort & 5 & Anti-U1snRNP & $\begin{array}{l}\text { ELISA, CIE, } \\
\text { dot blot, DID }\end{array}$ & $\begin{array}{l}\text { Muscle weakness is present } \\
\text { since the onset, with pulmonary } \\
\text { manifestations, neurological } \\
\text { symptoms, and symmetric } \\
\text { arthritis involving distal joints }\end{array}$ \\
\hline Hervier (81) & 2012 & $\begin{array}{l}\text { Anti- } \\
\text { synthetase } \\
\text { syndrome }\end{array}$ & Cohort & 233 & $\begin{array}{l}\text { Anti-synthetase } \\
\text { antibodies (anti- } \\
\text { Jo-1, anti-PL-7, } \\
\text { anti-PL-12) }\end{array}$ & $\mathrm{N} / \mathrm{A}$ & $\begin{array}{l}\text { Anti-PL7 and PL12 are very } \\
\text { similar and clearly distinct from } \\
\text { anti-Jo1 patients for reduced } \\
\text { survival ( } \mathrm{P}=0.012) \text { and had } \\
\text { higher frequency of ILD (98\%) }\end{array}$ \\
\hline Hervier (82) & 2013 & $\begin{array}{l}\text { Anti- } \\
\text { synthetase } \\
\text { syndrome }\end{array}$ & Cohort & 203 & $\begin{array}{l}\text { Anti-synthetase } \\
\text { antibodies (anti- } \\
\text { Jo1, anti-PL-7, } \\
\text { anti-PL-12 }\end{array}$ & Immunodot & $\begin{array}{l}\text { Anti-PL7 and PL12 were } \\
\text { associated at multivariate } \\
\text { analysis to increased risk of } \\
\text { death (OR } 6.3,95 \% \mathrm{Cl}: 1.1-35.4 \text {, } \\
\mathrm{P}=0.038) \text {. }\end{array}$ \\
\hline Lega (44) & 2010 & $\begin{array}{l}\text { PM/DM, } \\
\text { UCTD, IcSSc, } \\
\text { amyopathic } \\
\text { DM, overlap } \\
\text { syndrome } \\
\text { amyopathic } \\
\text { DM/SSc/SjS }\end{array}$ & Cohort & $\begin{array}{l}9 \text { anti-PM-Scl, } 12 \\
\text { anti-ARS ( } 7 \text { anti-Jo1, } \\
3 \text { anti-PL7, } 1 \text { anti-EJ, } \\
1 \text { double-positive for } \\
\text { anti-EJ and anti-OJ), } \\
1 \text { anti-PM-Scl and } \\
\text { anti-ARS }\end{array}$ & $\begin{array}{l}\text { Anti-PM-Scl; } \\
\text { Anti-ARS }\end{array}$ & $\begin{array}{l}\text { ELISA, } \\
\text { immunodot, } \\
\text { IP }\end{array}$ & $\begin{array}{l}\text { Extrapulmonary manifestations } \\
\text { of CTD in all patients, except } 1 \\
\text { with anti-PM-Scl }\end{array}$ \\
\hline $\begin{array}{l}\text { Nakashima } \\
\text { (84) }\end{array}$ & 2010 & SARD & $\begin{array}{l}\text { Case- } \\
\text { control }\end{array}$ & $192 / 21$ & $\begin{array}{l}\text { Anti-CADM-140/ } \\
\text { MDA5 }\end{array}$ & IP & $\begin{array}{l}\text { 11/13 patients positive for } \\
\text { anti-CADM-140/MDA5 were } \\
\text { diagnosed with CADM. Anti- } \\
\text { CADM-140/MDA5 antibodies are } \\
\text { strongly associated with rapidly } \\
\text { progressive ILD }\end{array}$ \\
\hline
\end{tabular}

Table 3 (continued) 
Table 3 (continued)

\begin{tabular}{|c|c|c|c|c|c|c|c|}
\hline Study & Year & Disease & $\begin{array}{l}\text { Study } \\
\text { design }\end{array}$ & $\begin{array}{l}\text { Number of cases/ } \\
\text { controls }\end{array}$ & Autoantibody & Methods & Main results \\
\hline Neri (85) & 2014 & $\begin{array}{l}\text { PM/DM, } \\
\text { cancer- } \\
\text { associated } \\
\text { myopathy } \\
\text { (CAM) }\end{array}$ & Cohort & $\begin{array}{l}162 \text { (PM 80, } 55 \text { DM, } \\
\text { CAM 27) }\end{array}$ & $\begin{array}{l}\text { Anti-Jo-1; Anti- } \\
\text { RNP }\end{array}$ & IIF, CIE & $\begin{array}{l}\text { CAM were observed in } 27 \\
\text { patients }(17 \%) \text {. Breast and } \\
\text { ovarian cancers were the more } \\
\text { common ( } 8 \text { and } 6 \text { patients). } \\
\text { CAM were strongly associated } \\
\text { with DM ( } 24.6 \% \text { vs. } 10.1 \% \text { in } \\
\text { PM), older age and dysphagia at } \\
\text { disease onset ( } 37 \% \text { vs. } 18.5 \% \text { in } \\
\text { IIM) }\end{array}$ \\
\hline $\begin{array}{l}\text { Pinal- } \\
\text { Fernandez } \\
\text { (86) }\end{array}$ & 2016 & IMNM & Cohort & 666 & $\begin{array}{l}\text { Anti-SRP; Anti- } \\
\text { HMGCR }\end{array}$ & ELISA, IP & $\begin{array}{l}\text { Anti-SRP positive patients were } \\
\text { younger and more commonly } \\
\text { under immunosuppressive } \\
\text { therapy than anti-HMGCR }(38.4 \\
\text { vs. } 53.3 \text { years old, } \mathrm{P}<0.001 ; 68 \% \\
\text { vs. } 40 \%, \mathrm{P}=0.03)\end{array}$ \\
\hline Pluk (87) & 2013 & $\begin{array}{l}\text { Sporadic } \\
\text { inclusion body } \\
\text { myositis, PM/ } \\
\text { DM and HC }\end{array}$ & $\begin{array}{l}\text { Case- } \\
\text { control }\end{array}$ & $\begin{array}{l}94 \text { sIBM, } 24 \text { DM, } 22 \\
\text { PM, } 94 \text { NDM, } 32 \text { HC }\end{array}$ & Anti-Mup44 & $\begin{array}{l}\text { IB, cDNA } \\
\text { cloning and } \\
\text { expression } \\
\text { of Mup44, IP, } \\
\text { microarray- } \\
\text { based } \\
\text { epitope } \\
\text { mapping }\end{array}$ & $\begin{array}{l}\text { The Mr } 44,000 \text { polypeptide } \\
\text { (Mup44) was identified as } \\
\text { cytosolic } 50 \text {-nucleotidase } \\
1 \mathrm{~A} \text { (cN1A). Anti-Mup44 was } \\
\text { detected in } 60 \% \text { of the sIBM } \\
\text { sera at high titer. The } 3 \text { major } \\
\text { autoepitope regions of cN1A } \\
\text { suggest that relatively small } \\
\text { fragments of this protein can } \\
\text { be used to detect anti-Mup44 } \\
\text { in patient sera. One of these } \\
\text { regions (aa221-243) were } \\
\text { recognized by all of the anti- } \\
\text { Mup44 positive slBM sera, but } \\
\text { not by the sera from HC }\end{array}$ \\
\hline $\begin{array}{l}\text { Watanabe } \\
(89)\end{array}$ & 2016 & IMNM & Cohort & 460 & $\begin{array}{l}\text { Anti-SRP; Anti- } \\
\text { HMGCR }\end{array}$ & $\begin{array}{l}\text { ELISA, RNA } \\
\text { IP }\end{array}$ & $\begin{array}{l}\text { Anti-SRP antibodies are } \\
\text { associated with more severe } \\
\text { muscle involvement compared } \\
\text { to anti-HMGCR }(63 \% \text { vs. } \\
24 \%, P<0.001) \text {, who had more } \\
\text { frequently statin exposure }(18 \% \\
\text { vs. } 4 \%, P=0.019)\end{array}$ \\
\hline
\end{tabular}

ARS, aminoacyl-tRNA synthetases; ALBIA, addressable laser bead immunoassay; CAM, cancer-associated idiopathic inflammatory myopathy; CIE, counterimmunoelectrophoresis, CTD, connective tissue disease; DID, double immunodiffusion; DM, dermatomyositis; ELISA, enzyme linked immunosorbent assay; dcSSc, diffuse cutaneous systemic sclerosis; HC, healthy controls; HMGCR, 3-hydroxy-3methylglutaryl-coenzyme A reductase; IB, immunoblotting; IIF, indirect immunofluorescence; ILD, interstitial lung disease; IMNM, immunemediated necrotizing myopathy; IP, immunoprecipitation; IcSSc, limited cutaneous systemic sclerosis; N/A, not available; PM/DM, polymyositis/dermatomyositis; SARD, systemic autoimmune rheumatic diseases; SRP, signal recognition particle; SSc, systemic sclerosis; UCTD, undifferentiated connective tissue disease; WB, western blot. 
A distinct subset of DM, called clinically amyopathic DM (CADM), has been associated with anti-CADM-140/MDA5 antibodies which are strongly related to rapidly progressive ILD (84) and in cases of anti-CADM-140/MDA5 positive patients with idiopathic pulmonary fibrosis (110).

\section{AutoAbs in MCTD, Sjögren's syndrome (SjS) and other rheumatic diseases}

MCTD is characterized by the overlap of SSc, SLE and RA diagnosis in the presence of autoAbs such as anti-synthetase antibodies, described in previous sections of this review. Other undefined autoAbs directed towards tRNA were identified in about $1.9 \%$ of sera from patients with SARD, and nearly all the positive sera belonged to patients affected by either SLE or SjS. Subjects with both anti-tRNA synthetase antibodies and anti-RoSSA/LaSSB (57.1\%) develop annular or papulosquamous recurrent erythema in $37.5 \%$ of cases (111). Antibodies to NOR 90 were first described in a patient with SSc by Rodriguez-Sanchez et al., who identified a novel $90-\mathrm{kDa}$ protein recognized by autoantibodies that selectively stained the nucleolusorganizing region (NOR) of chromosomes 13, 14, 15, 21, and 22 (112). The $90-\mathrm{kDa}$ autoantigen was later shown to be identical to human upstream-binding factor (hUBF), an RNA polymerase I-specific transcription factor which plays a central role in transcriptional regulation of rRNA (113). In search for the NOR 90 specificity among 254 patients with various autoimmune rheumatic diseases, RodriguezSanchez et al. concluded that anti-NOR 90 antibodies were associated with SSc. By contrast, Kipnis et al. did not detect anti-NOR 90 in sera from 112 patients with SSc (41), while Imai et al. (114) and Dick et al. (115) reported the presence of antibodies to NOR 90 in patients with heterogeneous conditions, including SSc, SLE, RA, SjS, UCTD and other non-rheumatic diseases..

Among patients with $\mathrm{SjS}$, the occurrence of several rare autoAbs and uncommon clinical presentations (such as severe motor-dominant weakness in the lower extremities, depression, cerebellar ataxia) have been described, for example in a patient with anti-neuronal antibodies (116) and in a patient with antibodies to $\mathrm{Ma} 2 / \mathrm{Ta}$ with progressive spastic paresis without evidence of cancer over a 4-year follow-up (117). One case of anti-aquaporin 4 antibodies positivity had tetraparesis due to recurrent central nervous system demyelination, together with distal renal tubular acidosis, hypokalemia, medullary nephrocalcinosis, respiratory failure, and secondary anti-phospholipid syndrome (118). Vandergheynst et al. report the occurrence of anti-PM-Scl antibodies in one patient with $\mathrm{SjS}$ and ILD, without features of SSc or myositis (99).

AutoAbs against the mitotic apparatus (MA) represent a subtype of ANA rarely detected in sera from patients with SARD. Different MA antigens have been identified so far: mitotic spindle apparatus (MSA), centrosome (CE), midbody (MB/MSA-2), and centromere-F (CENP-F) (119). After the description of anti-MSA antibodies by McCarty $e t$ al. in 1981 (120), two major classes were identified: autoAbs against the nuclear mitotic apparatus protein (NuMA) and the kinesin-like protein $\mathrm{HsEg} 5(121,122)$. Their prevalence is estimated to be less than $1 \%$, with anti-HsEg 5 being less frequently detected than anti-NuMA $(123,124)$. Antimitotic spindle apparatus antibodies appear to be primarily associated with SjS, SLE and UCTD (26,121-124), and the most frequent clinical symptoms are arthralgia and sicca syndrome (26).

\section{Discussion}

SARD are characterized by the presence of serum autoAbs directed against cellular components belonging to different tissues and organs, and in this view the first step to recognize the presence of an autoimmune response in a specific clinical setting is the identification of autoAbs. However, autoAbs and serum ANA are not disease specific for rheumatic diseases and they can be present also in a significant proportion of healthy people (3), as well as in other autoimmune conditions, i.e., autoimmune thyroid disease (125). AutoAbs specific for SARD have been identified and described since the 1990s, and albeit the most known (i.e., anti-dsDNA and anti-RoSSA/LaSSB), which are also included in the disease classification criteria $(126,127)$ and easily tested in routine assays (128), many others are rare and they are not available for the routine testing. In this view, rheumatologists treating SARD should know also the prevalence and clinical associations of rare autoAbs, especially for particular rheumatic disease subsets and their possible association with malignancy (129). The results of the present systematic literature summarize the main features of rare serum autoAbs identified in SARD, as described in Tables 1-4, and a few novel findings have been identified. For example, the number of autoAbs targeting the nervous system, as well as the field of neuroimmunology, have enormously increased (131). In the present work, we have retrieved several articles regarding anti-neuronal antibodies in NPSLE $(17,18,29,32)$, however, most of them 
Table 4 Prevalence and clinical significance of rare serum autoAbs in mixed connective tissue disease (MCTD), Sjögren's syndrome (SjS) and other connective tissue diseases (CTDs)

\begin{tabular}{|c|c|c|c|c|c|c|c|}
\hline Study & Year & Disease & $\begin{array}{l}\text { Study } \\
\text { design }\end{array}$ & $\begin{array}{l}\text { Number } \\
\text { of cases/ } \\
\text { controls }\end{array}$ & Autoantibody & Methods & Main results \\
\hline $\begin{array}{l}\text { Bonaci- } \\
\text { Nikolic (123) }\end{array}$ & 2006 & $\begin{array}{l}\text { SjS } \\
\text { UCTD }\end{array}$ & Cohort & 6,270 & $\begin{array}{l}\text { Anti-NuMA1; } \\
\text { Anti-NuMA2 } \\
\text { (HsEg5); } \\
\text { Anti-CENP F; } \\
\text { Anti-CENP F/ } \\
\text { centrosome }\end{array}$ & IIF, ELISA & $\begin{array}{l}\text { Anti-NuMA1 antibodies were found in } 23 \\
\text { ( } 41 \%) \text { and -NuMA2 in } 7 \text { patients. Most } \\
\text { of the positive patients had CTD ( } 22 / 43 \text {, } \\
51.1 \%) \text {, UCTD ( } 7 / 22) \text { and SjS ( } 6 / 22) \text { being } \\
\text { the most common. Anti-NuMA1 positivity } \\
\text { was associated with SjS, while patients } \\
\text { with -NuMA2 had various diseases } \\
\text { ( } 1 \mathrm{SSc}, 2 \mathrm{AlH}, 1 \text { infection, } 1 \text { vasculitis) }\end{array}$ \\
\hline Mozo (124) & 2008 & $\begin{array}{l}\text { SjS, } \\
\text { UCTD, } \\
\text { SLE }\end{array}$ & Cohort & 47 & $\begin{array}{l}\text { Anti-NuMA; } \\
\text { Anti-HsEg5 }\end{array}$ & $\begin{array}{l}\text { IIF, IB, ELISA, } \\
\text { chemiluminescence, } \\
\text { radioimmunoassay }\end{array}$ & $\begin{array}{l}\text { NuMA positivity was mainly associated } \\
\text { with SjS/sicca syndrome and UCTD. } \\
\text { Anti-HsEg5 antibodies were detected in } \\
7 \text { patients, not associated with a specific } \\
\text { SARD }\end{array}$ \\
\hline $\begin{array}{l}\text { Owada } \\
(116)\end{array}$ & 2002 & SjS & $\begin{array}{l}\text { Case } \\
\text { report }\end{array}$ & 1 & $\begin{array}{l}\text { Anti-neuronal } \\
\text { antibodies }\end{array}$ & $\begin{array}{l}\text { Immunohistochemistry, } \\
\text { WB }\end{array}$ & $\begin{array}{l}\text { Severe motor-dominant weakness in } \\
\text { the lower extremities, depressive state, } \\
\text { cerebellar ataxia, bladder disturbance } \\
\text { were present in this patient }\end{array}$ \\
\hline $\begin{array}{l}\text { Rajagopala } \\
\text { (118) }\end{array}$ & 2015 & SjS & $\begin{array}{l}\text { Case } \\
\text { report }\end{array}$ & 1 & $\begin{array}{l}\text { Anti- } \\
\text { aquaporin-4 } \\
\text { antibodies }\end{array}$ & ELISA & $\begin{array}{l}\text { SjS with distal renal tubular } \\
\text { acidosis, hypokaliemia, medullary } \\
\text { nephrocalcinosis, recurrent central } \\
\text { nervous system demyelination with } \\
\text { tetraparesis, respiratory failure, } \\
\text { secondary anti-phospholipids with } \\
\text { intravenous catheter thrombosis }\end{array}$ \\
\hline $\begin{array}{l}\text { Whitehead } \\
\text { (122) }\end{array}$ & 1996 & SLE, SjS & Cohort & $\begin{array}{l}51 \text { MSA- } \\
\text { positive sera } \\
\text { (43 NuMA, } \\
7 \text { HsEg5); } \\
52 \text { SLE sera }\end{array}$ & $\begin{array}{l}\text { Anti-NuMA2 } \\
\text { (HsEg5) }\end{array}$ & IIF, IB, IP & $\begin{array}{l}\text { Five of the } 7 \text { HsEg5-positive sera had } \\
\text { SLE, } 1 \text { had possible SLE, and } 2 \text { had } \\
\text { SjS. The anti-HsEg5 activity did not } \\
\text { decrease in titer over time, and there was } \\
\text { no apparent association with disease } \\
\text { activity }\end{array}$ \\
\hline
\end{tabular}

CTD, connective tissue disease; ELISA, enzyme linked immunosorbent assay; IB, immunoblotting; IIF, indirect immunofluorescence; IP, immunoprecipitation; MSA, myositis specific antibodies; RA, rheumatoid arthritis; SLE, systemic lupus erythematosus; SjS, Sjögren's syndrome; SSc, systemic sclerosis; UCTD, undifferentiated connective tissue disease. 
are case reports or small case series, thus estimating the prevalence of these autoAbs remains difficult. Lastly, we confirm that an autoAb called "anti-DFS70" which stands for diffuse speckled pattern at IIF has been associated negatively with SARD, as it is more frequent in healthy subjects (73-76,132-135) and it is rare in SLE patients (132), thus maybe representing a protective pattern.

We must acknowledge that a large variability is found when searching for rare autoAbs in SARD, and additional unsolved problems are represented by the lack of validation, the small number of cases described with different prevalence in different ethnic groups and the use of different laboratory methods for autoAb identification. Further research is needed to strengthen evidence for the role of such autoAbs in the clinical assessment of specific diseases.

\section{Acknowledgements}

This project has been supported by the contribution of the Italian Ministry of Foreign Affairs (Ministero degli Affari Esteri e della Cooperazione Internazionale, Direzione Generale per la Promozione del Sistema Paese).

\section{Footnote}

Conflicts of Interest: The authors have no conflicts of interest to declare.

\section{References}

1. Satoh M, Chan EK, Sobel ES, et al. Clinical implication of autoantibodies in patients with systemic rheumatic diseases. Expert Rev Clin Immunol 2007;3:721-38.

2. Arbuckle MR, McClain MT, Rubertone MV, et al. Development of autoantibodies before the clinical onset of systemic lupus erythematosus. $\mathrm{N}$ Engl J Med 2003;349:1526-33.

3. Selmi C, Ceribelli A, Generali E, et al. Serum antinuclear and extractable nuclear antigen antibody prevalence and associated morbidity and mortality in the general population over 15 years. Autoimmun Rev 2016;15:162-6.

4. Venables PJ. Mixed connective tissue disease. Lupus 2006;15:132-7.

5. Ceribelli A, Isailovic N, De Santis M, et al. Myositisspecific autoantibodies and their association with malignancy in Italian patients with polymyositis and dermatomyositis. Clin Rheumatol 2017;36:469-75.
6. de Leeuw K, Bungener L, Roozendaal C, et al. Autoantibodies to double-stranded DNA as biomarker in systemic lupus erythematosus: comparison of different assays during quiescent and active disease. Rheumatology (Oxford) 2017;56:698-703.

7. Ho KT, Reveille JD. The clinical relevance of autoantibodies in scleroderma. Arthritis Res Ther 2003;5:80-93.

8. Satoh M, Tanaka S, Ceribelli A, et al. A Comprehensive Overview on Myositis-Specific Antibodies: New and Old Biomarkers in Idiopathic Inflammatory Myopathy. Clin Rev Allergy Immunol 2017;52:1-19.

9. Conrad K, Rober N, Andrade LE, et al. The Clinical Relevance of Anti-DFS70 Autoantibodies. Clin Rev Allergy Immunol 2017;52:202-16.

10. Larosa $M$, Iaccarino $L$, Gatto $M$, et al. Advances in the diagnosis and classification of systemic lupus erythematosus. Expert Rev Clin Immunol 2016;12:1309-20.

11. Luggen ME, Gulati G, Zhang B, et al. Non-criteria antiphospholipid antibodies and cognitive impairment in SLE. Clin Rheumatol 2016;35:93-9.

12. Aggarwal R, Ringold S, Khanna D, et al. Distinctions between diagnostic and classification criteria? Arthritis Care Res (Hoboken) 2015;67:891-7.

13. June RR, Aggarwal R. The use and abuse of diagnostic/ classification criteria. Best Pract Res Clin Rheumatol 2014;28:921-34.

14. Moher D, Liberati A, Tetzlaff J, et al. Preferred reporting items for systematic reviews and meta-analyses: the PRISMA statement. Ann Intern Med 2009;151:264-9, W64.

15. Black DR, Hornung CA, Schneider PD, et al. Frequency and severity of systemic disease in patients with subacute cutaneous lupus erythematosus. Arch Dermatol 2002;138:1175-8.

16. Eystathioy T, Chan EK, Takeuchi K, et al. Clinical and serological associations of autoantibodies to $\mathrm{GW}$ bodies and a novel cytoplasmic autoantigen GW182. J Mol Med (Berl) 2003;81:811-8.

17. Hagberg N, Theorell J, Eloranta M, et al. AntiNKG2A autoantibodies in a patient with systemic lupus erythematosus. Rheumatology (Oxford) 2013;52:1818-23.

18. Karaaslan Z, Ekizoğlu E, Tektürk P, et al. Investigation of neuronal auto-antibodies in systemic lupus erythematosus patients with epilepsy. Epilepsy Res 2017;129:132-7.

19. Lee CK, Ahn MS, Lee EY, et al. Acute abdominal pain in systemic lupus erythematosus: focus on lupus enteritis (gastrointestinal vasculitis). Ann Rheum Dis 2002;61:547-50. 
20. Lin H, Wei JC, Tan CY, et al. Survival analysis of lateonset systemic lupus erythematosus: a cohort study in China. Clin Rheumatol 2012;31:1683-9.

21. Matsumoto I, Lee DM, Goldbach-Mansky R, et al. Low prevalence of antibodies to glucose-6-phosphate isomerase in patients with rheumatoid arthritis and a spectrum of other chronic autoimmune disorders. Arthritis Rheum 2003;48:944-54.

22. Patsinakidis N, Gambichler T, Lahner N, et al. Cutaneous characteristics and association with antinuclear antibodies in 402 patients with different subtypes of lupus erythematosus. J Eur Acad Dermatol Venereol 2016;30:2097-104.

23. Su YJ, Huang CR, Chang WN, et al. The association between autoantibodies and peripheral neuropathy in lupus nephritis. Biomed Res Int 2014;2014:524940.

24. van Venrooij WJ, Hoet R, Castrop J, et al. Anti-(U1) small nuclear RNA antibodies in anti-small nuclear ribonucleoprotein sera from patients with connective tissue diseases. J Clin Invest 1990;86:2154-60.

25. Wang J, Satoh M, Kabir F, et al. Increased prevalence of autoantibodies to ku antigen in African American versus white patients with systemic lupus erythematosus. Arthritis Rheum 2001;44:2367-70.

26. Xi Q, Wu Y, Li L, et al. Anti-Mitotic Spindle Apparatus Antoantibodies: Prevalence and Disease Association in Chinese Population. J Clin Lab Anal 2016;30:702-8.

27. Yamasaki Y, Narain S, Hernandez L, et al. Autoantibodies against the replication protein A complex in systemic lupus erythematosus and other autoimmune diseases. Arthritis Res Ther 2006;8:R111.

28. Katsanos KH, Voulgari PV, Goussia A, et al. Coexistence of Crohn's disease in a patient with systemic lupus erythematosus. Rheumatol Int 2013;33:2145-8.

29. Shih WH, Landau ME, Barner KC, et al. Acquired neuromyotonia in association with systemic lupus erythematosus. J Clin Neuromuscul Dis 2003;5:8-11.

30. Singh R, Huang W, Menon Y, et al. Shrinking lung syndrome in systemic lupus erythematosus and Sjogren's syndrome. J Clin Rheumatol 2002;8:340-5.

31. Okano Y, Targoff IN, Oddis CV, et al. Anti-U5 small nuclear ribonucleoprotein (snRNP) antibodies: a rare anti-U snRNP specificity. Clin Immunol Immunopathol 1996;81:41-7.

32. Castro A, Romeu JC, Geraldes R, et al. Encephalopathy with upper body hypertonia and myoclonus in patient with systemic lupus erythematosus and anti-CASPR2. Lupus 2017;26:84-7.
33. Chang M, Wang RJ, Yangco DT, et al. Analysis of autoantibodies against RNA polymerases using immunoaffinity-purifed RNA polymerase I, II, and III antigen in an enzyme-linked immunosorbent assay. Clin Immunol Immunopathol 1998;89:71-8.

34. Airo' P, Ceribelli A, Cavazzana I, et al. Malignancies in Italian patients with systemic sclerosis positive for anti-RNA polymerase III antibodies. J Rheumatol 2011;38:1329-34.

35. Arnett FC, Reveille JD, Goldstein R, et al. Autoantibodies to fibrillarin in systemic sclerosis (scleroderma). An immunogenetic, serologic, and clinical analysis. Arthritis Rheum 1996;39:1151-60.

36. Ceribelli A, Krzyszczak ME, Li Y, et al. Atypical clinical presentation of a subset of patients with anti-RNA polymerase III--non-scleroderma cases associated with dominant RNA polymerase I reactivity and nucleolar staining. Arthritis Res Ther 2011;13:R119.

37. Codullo V, Cavazzana I, Bonino C, et al. Serologic profile and mortality rates of scleroderma renal crisis in Italy. J Rheumatol 2009;36:1464-9.

38. Derrett-Smith EC, Nihtyanova SI, Harvey J, et al. Revisiting ANCA-associated vasculitis in systemic sclerosis: clinical, serological and immunogenetic factors. Rheumatology (Oxford) 2013;52:1824-31.

39. Hudson M, Luck Y, Stephenson M, et al. Anti-HMGCR antibodies in systemic sclerosis. Medicine (Baltimore) 2016;95:e5280.

40. Jaeger VK, Wirz EG, Allanore Y, et al. Incidences and risk factors of organ manifestations in the early course of systemic sclerosis: A longitudinal EUSTAR study. PLoS One 2016;11(10).

41. Kipnis RJ, Craft J, Hardin JA. The analysis of antinuclear and antinucleolar autoantibodies of scleroderma by radioimmunoprecipitation assays. Arthritis Rheum 1990;33:1431-7.

42. Krzyszczak ME, Li Y, Ross SJ, et al. Gender and ethnicity differences in the prevalence of scleroderma-related autoantibodies. Clin Rheumatol 2011;30:1333-9.

43. Kuwana M, Kaburaki J, Okano Y, et al. Clinical and prognostic associations based on serum antinuclear antibodies in Japanese patients with systemic sclerosis. Arthritis Rheum 1994;37:75-83.

44. Lega JC, Cottin V, Fabien N, et al. Interstitial lung disease associated with anti-PM/Scl or anti-aminoacyltRNA synthetase autoantibodies: a similar condition? J Rheumatol 2010;37:1000-9.

45. Maes L, Blockmans D, Verschueren P, et al. Anti-PM/ 
Scl-100 and anti-RNA-polymerase III antibodies in scleroderma. Clin Chim Acta 2010;411:965-71.

46. McNearney TA, Reveille JD, Fischbach M, et al. Pulmonary involvement in systemic sclerosis: associations with genetic, serologic, sociodemographic, and behavioral factors. Arthritis Rheum 2007;57:318-26.

47. Mierau R, Moinzadeh P, Riemekasten G, et al. Frequency of disease-associated and other nuclear autoantibodies in patients of the German Network for Systemic Scleroderma: correlation with characteristic clinical features. Arthritis Res Ther 2011;13:R172.

48. Moinzadeh P, Fonseca C, Hellmich M, et al. Association of anti-RNA polymerase III autoantibodies and cancer in scleroderma. Arthritis Res Ther 2014;16:R53.

49. Motegi S, Toki S, Yamada K, et al. Demographic and clinical features of systemic sclerosis patients with anti-RNA polymerase III antibodies. J Dermatol 2015;42:189-92.

50. Nikpour M, Hissaria P, Byron J, et al. Prevalence, correlates and clinical usefulness of antibodies to RNA polymerase III in systemic sclerosis: a cross-sectional analysis of data from an Australian cohort. Arthritis Res Ther 2011;13:R211.

51. Okano Y, Steen VD, Medsger TA, Jr. Autoantibody to U3 nucleolar ribonucleoprotein (fibrillarin) in patients with systemic sclerosis. Arthritis Rheum 1992;35:95-100.

52. Reimer G, Steen VD, Penning CA, et al. Correlates between autoantibodies to nucleolar antigens and clinical features in patients with systemic sclerosis (scleroderma). Arthritis Rheum 1988;31:525-32.

53. Reveille JD, Fischbach M, McNearney T, et al. Systemic sclerosis in 3 US ethnic groups: a comparison of clinical, sociodemographic, serologic, and immunogenetic determinants. Semin Arthritis Rheum 2001;30:332-46.

54. Saigusa R, Asano Y, Nakamura K, et al. Association of antiRNA polymerase III antibody and malignancy in Japanese patients with systemic sclerosis. J Dermatol 2015;42:524-7.

55. Sujau I, Ng CT, Sthaneshwar P, et al. Clinical and autoantibody profile in systemic sclerosis: baseline characteristics from a West Malaysian cohort. Int J Rheum Dis 2015;18:459-65.

56. Yang JM, Hildebrandt B, Luderschmidt C, et al. Human scleroderma sera contain autoantibodies to protein components specific to the U3 small nucleolar RNP complex. Arthritis Rheum 2003;48:210-7.

57. Reimer G, Scheer U, Peters JM, et al. Immunolocalization and partial characterization of a nucleolar autoantigen (PM-Scl) associated with polymyositis/scleroderma overlap syndromes. J Immunol 1986;137:3802-8.
58. Ge Q, Wu Y, Trieu EP, et al. Analysis of the specificity of anti-PM-Scl autoantibodies. Arthritis Rheum 1994;37:1445-52.

59. Sharif R, Fritzler MJ, Mayes MD, et al. Anti-fibrillarin antibody in African American patients with systemic sclerosis: immunogenetics, clinical features, and survival analysis. J Rheumatol 2011;38:1622-30.

60. Tall F, Dechomet M, Riviere S, et al. The Clinical Relevance of Antifibrillarin (anti-U3-RNP) Autoantibodies in Systemic Sclerosis. Scand J Immunol 2017;85:73-9.

61. Tormey VJ, Bunn CC, Denton CP, et al. Anti-fibrillarin antibodies in systemic sclerosis. Rheumatology (Oxford) 2001;40:1157-62.

62. Patterson KA, Roberts-Thomson PJ, Lester S, et al. Interpretation of an Extended Autoantibody Profile in a Well-Characterized Australian Systemic Sclerosis (Scleroderma) Cohort Using Principal Components Analysis. Arthritis Rheumatol 2015;67:3234-44.

63. Melani L, Cardinali C, Giomi B, et al. Case study: periodic follow-up is necessary in morphea profunda to identify systemic evolution. Skinmed 2005;4:188-90.

64. Melani L, Caproni M, Cardinali C, et al. A case of nodular scleroderma. J Dermatol 2005;32:1028-31.

65. van den Hoogen F, Khanna D, Fransen J, et al. 2013 classification criteria for systemic sclerosis: an American college of rheumatology/European league against rheumatism collaborative initiative. Ann Rheum Dis 2013;72:1747-55.

66. Ceribelli A, Cavazzana I, Airo P, et al. Anti-RNA polymerase III antibodies as a risk marker for early gastric antral vascular ectasia (GAVE) in systemic sclerosis. J Rheumatol 2010;37:1544.

67. Cavazzana I, Ceribelli A, Airo P, et al. Anti-RNA polymerase III antibodies: a marker of systemic sclerosis with rapid onset and skin thickening progression. Autoimmun Rev 2009;8:580-4.

68. Wielosz E, Dryglewska M, Majdan M. Serological profile of patients with systemic sclerosis. Postepy Hig Med Dosw (Online) 2014;68:987-91.

69. Shah AA, Rosen A, Hummers L, et al. Close temporal relationship between onset of cancer and scleroderma in patients with RNA polymerase I/III antibodies. Arthritis Rheum 2010;62:2787-95.

70. Hirohata S, Ohse T, Takeuchi A, et al. Systemic sclerosis complicated with nephrotic syndrome: relevance with antiribosomal P antibody. Rheumatol Int 2001;21:40-3.

71. Ngo LQ, Wu AG, Nguyen MA, et al. A case report of autoimmune necrotizing myositis presenting as dysphagia 
and neck swelling. BMC Ear Nose Throat Disord 2016;16:7.

72. Nichols L, Pfeifer K, Mammen AL, et al. An Unusual Case of Statin-Induced Myopathy: Anti-HMGCoA Necrotizing Autoimmune Myopathy. J Gen Intern Med 2015;30:1879-83.

73. Bizzaro N, Tonutti E, Tampoia M, et al. Specific chemoluminescence and immunoasdorption tests for antiDFS70 antibodies avoid false positive results by indirect immunofluorescence. Clin Chim Acta 2015;451:271-7.

74. Mahler M, Parker T, Peebles CL, et al. Anti-DFS70/ LEDGF antibodies are more prevalent in healthy individuals compared to patients with systemic autoimmune rheumatic diseases. J Rheumatol 2012;39:2104-10.

75. Watanabe A, Kodera M, Sugiura K, et al. Anti-DFS70 antibodies in 597 healthy hospital workers. Arthritis Rheum 2004;50:892-900.

76. Muro Y, Sugiura K, Morita Y, et al. High concomitance of disease marker autoantibodies in anti-DFS70/LEDGF autoantibody-positive patients with autoimmune rheumatic disease. Lupus 2008;17:171-6.

77. Allenbach Y, Drouot L, Rigolet A, et al. Anti-HMGCR autoantibodies in European patients with autoimmune necrotizing myopathies: inconstant exposure to statin. Medicine (Baltimore) 2014;93:150-7.

78. Alvarado-Cardenas M, Marin-Sanchez A, Martinez MA, et al. Statin-associated autoimmune myopathy: A distinct new IFL pattern can increase the rate of HMGCR antibody detection by clinical laboratories. Autoimmun Rev 2016;15:1161-6.

79. Coppo P, Clauvel JP, Bengoufa D, et al. Inflammatory myositis associated with anti-U1-small nuclear ribonucleoprotein antibodies: a subset of myositis associated with a favourable outcome. Rheumatology (Oxford) 2002;41:1040-6.

80. Drouot L, Allenbach Y, Jouen F, et al. Exploring necrotizing autoimmune myopathies with a novel immunoassay for anti-3-hydroxy-3-methyl-glutaryl-CoA reductase autoantibodies. Arthritis Res Ther. 2014;16:R39.

81. Hervier B, Devilliers H, Stanciu R, et al. Hierarchical cluster and survival analyses of antisynthetase syndrome: Phenotype and outcome are correlated with antitRNA synthetase antibody specificity. Autoimmun Rev 2012;12:210-7.

82. Hervier B, Meyer A, Dieval C, et al. Pulmonary hypertension in antisynthetase syndrome: Prevalence, aetiology and survival. Eur Respir J 2013;42:1271-82.
83. Hirakata M, Suwa A, Takada T, et al. Clinical and immunogenetic features of patients with autoantibodies to asparaginyl-transfer RNA synthetase. Arthritis Rheum 2007;56:1295-303.

84. Nakashima R, Imura Y, Kobayashi S, et al. The RIG-Ilike receptor IFIH1/MDA5 is a dermatomyositis-specific autoantigen identified by the anti-CADM-140 antibody. Rheumatology (Oxford) 2010;49:433-40.

85. Neri R, Barsotti S, Iacopetti V, et al. Cancer-associated myositis: a 35-year retrospective study of a monocentric cohort. Rheumatol Int 2014;34:565-9.

86. Pinal-Fernandez I, Casal-Dominguez M, Carrino JA, et al. Thigh muscle MRI in immune-mediated necrotising myopathy: extensive oedema, early muscle damage and role of anti-SRP autoantibodies as a marker of severity. Ann Rheum Dis 2017;76:681-7.

87. Pluk $\mathrm{H}$, van Hoeve $\mathrm{BJ}$, van Dooren $\mathrm{SH}$, et al. Autoantibodies to cytosolic 5'-nucleotidase 1A in inclusion body myositis. Ann Neurol 2013;73:397-407.

88. Watanabe K, Handa T, Tanizawa K, et al. Detection of antisynthetase syndrome in patients with idiopathic interstitial pneumonias. Respir Med 2011;105:1238-47.

89. Watanabe Y, Uruha A, Suzuki S, et al. Clinical features and prognosis in anti-SRP and anti-HMGCR necrotising myopathy. Journal of neurology, neurosurgery, and psychiatry. 2016;87:1038-44.

90. Fernandez C, Bardin N, De Paula AM, et al. Correlation of clinicoserologic and pathologic classifications of inflammatory myopathies: study of 178 cases and guidelines for diagnosis. Medicine (Baltimore) 2013;92:15-24.

91. Haydour Q, Wells MA, McCoy SS, et al. Anti-synthetase syndrome presenting as cryptogenic organizing pneumonia. Respir Med Case Rep 2012;6:13-5.

92. Sauty A, Rochat T, Schoch OD, et al. Pulmonary fibrosis with predominant CD8 lymphocytic alveolitis and antiJo-1 antibodies. Eur Respir J 1997;10:2907-12.

93. Gayathri Devi HJ, Majeed Pasha MD, Padmaja MS, et al. Antisynthetase syndrome: A rare cause for ILD. J Clin Diagn Res 2016;10:OD08-9.

94. Gormley M, Scully C. Antisynthetase syndrome: Two cases presenting orofacial manifestations. Br J Oral Maxillofac Surg 2014;52:285-7.

95. Brady S, Melath S, Scalco RS, et al. Fatal cardiac involvement complicating antisynthetase syndrome. BMJ Case Rep 2014;2014.

96. Suzuki S, Nishikawa A, Kuwana M, et al. Inflammatory myopathy with anti-signal recognition particle antibodies: case series of 100 patients. Orphanet J Rare Dis 
2015;10:61.

97. Kennedy N, Keating P, O'Donnell J. HMGCR-associated myositis: A New Zealand case series and estimate of incidence. Intern Med J 2016;46:622-5.

98. Sugie K, Tonomura Y, Ueno S. Characterization of dermatomyositis with coexistence of anti-Jo-1 and antiSRP antibodies. Intern Med 2012;51:799-802.

99. Vandergheynst F, Ocmant A, Sordet C, et al. Anti-pm/ scl antibodies in connective tissue disease: Clinical and biological assessment of 14 patients. Clin Exp Rheumatol 2006;24:129-33.

100. Wantke F, Kneussl M, Hubner M, et al. Signal recognition particle (SRP) positive myositis in a patient with cryptogenic organizing pneumonia (COP). Rheumatol Int 2010;30:1361-5.

101.Ferreira DM, Mendes PA, Aragão A, et al. Anti-signal recognition particle myopathy in a geriatric patient. Eur J Case Rep Intern Med 2015;2(7).

102.Shovman O, Gilburd B, Chayat C, et al. Anti-HMGCR antibodies demonstrate high diagnostic value in the diagnosis of immune-mediated necrotizing myopathy following statin exposure. Immunol Res 2017;65:276-81.

103. Musset L, Miyara M, Benveniste O, et al. Analysis of autoantibodies to 3-hydroxy-3-methylglutaryl-coenzyme A reductase using different technologies. J Immunol Res 2014;2014:405956.

104.Limaye V, Bundell C, Hollingsworth P, et al. Clinical and genetic associations of autoantibodies to 3-hydroxy3-methyl-glutaryl-coenzyme a reductase in patients with immune-mediated myositis and necrotizing myopathy. Muscle Nerve 2015;52:196-203.

105. Watanabe Y, Suzuki S, Nishimura H, et al. Statins and myotoxic effects associated with anti-3-hydroxy-3methylglutaryl-coenzyme A reductase autoantibodies: an observational study in Japan. Medicine (Baltimore) 2015;94:e416.

106. Werner JL, Christopher-Stine L, Ghazarian SR, et al. Antibody levels correlate with creatine kinase levels and strength in anti-3-hydroxy-3-methylglutaryl-coenzyme A reductase-associated autoimmune myopathy. Arthritis Rheum 2012;64:4087-93.

107. Musset L, Allenbach Y, Benveniste O, et al. AntiHMGCR antibodies as a biomarker for immune-mediated necrotizing myopathies: A history of statins and experience from a large international multi-center study. Autoimmun Rev 2016;15:983-93.

108. Mammen AL, Chung T, Christopher-Stine L, et al. Autoantibodies against 3-hydroxy-3-methylglutaryl- coenzyme A reductase in patients with statin-associated autoimmune myopathy. Arthritis Rheum 2011;63:713-21.

109. Kubeček O, Soukup T, Paulík A, et al. Dermatomyositis with anti-TIF- $1 \gamma$ antibodies as a presenting symptom of underlying triple-negative breast cancer: A case report. BMC Cancer 2016;16:684.

110. Sato S, Hoshino K, Satoh T, et al. RNA helicase encoded by melanoma differentiation-associated gene 5 is a major autoantigen in patients with clinically amyopathic dermatomyositis: Association with rapidly progressive interstitial lung disease. Arthritis Rheum 2009;60:2193-200.

111. Ohosone Y, Ishida M, Takahashi Y, et al. Spectrum and clinical significance of autoantibodies against transfer RNA. Arthritis Rheum 1998;41:1625-31.

112. Rodriguez-Sanchez JL, Gelpi C, Juarez C, et al. Anti-NOR 90. A new autoantibody in scleroderma that recognizes a 90-kDa component of the nucleolus-organizing region of chromatin. J Immunol 1987;139:2579-84.

113. Chan EK, Imai H, Hamel JC, et al. Human autoantibody to RNA polymerase I transcription factor hUBF. Molecular identity of nucleolus organizer region autoantigen NOR90 and ribosomal RNA transcription upstream binding factor. J Exp Med 1991;174:1239-44.

114. Imai H, Fritzler MJ, Neri R, et al. Immunocytochemical characterization of human NOR-90 (upstream binding factor) and associated antigens reactive with autoimmune sera. Two MR forms of NOR-90/hUBF autoantigens. Mol Biol Rep 1994;19:115-24.

115.Dick T, Mierau R, Sternfeld R, et al. Clinical relevance and HLA association of autoantibodies against the nucleolus organizer region (NOR-90). J Rheumatol 1995;22:67-72.

116. Owada K, Uchihara T, Ishida K, et al. Motor weakness and cerebellar ataxia in Sjogren syndrome--identification of antineuronal antibody: a case report. J Neurol Sci 2002;197:79-84.

117.Piccolo G, Tavazzi E, Jarius S, et al. Anti-Ma2/Ta antibodies in a woman with primary lateral sclerosislike phenotype and Sjogren syndrome. Neurol Sci 2011;32:915-7.

118. Rajagopala S, Danigeti G, Subrahmanyan D. An unusually dry story. Indian J Crit Care Med 2015;19:550-3.

119. Rattner JB, Mack GJ, Fritzler MJ. Autoantibodies to components of the mitotic apparatus. Mol Biol Rep 1998;25:143-55.

120.McCarty GA, Valencia DW, Fritzler MJ, et al. A unique antinuclear antibody staining only the mitotic-spindle apparatus. N Engl J Med 1981;305:703.

121. Andrade LE, Chan EK, Peebles CL, et al. Two major 
autoantigen-antibody systems of the mitotic spindle apparatus. Arthritis Rheum 1996;39:1643-53.

122. Whitehead CM, Winkfein RJ, Fritzler MJ, et al. The spindle kinesin-like protein $\mathrm{HsEg} 5$ is an autoantigen in systemic lupus erythematosus. Arthritis Rheum 1996;39:1635-42.

123. Bonaci-Nikolic B, Andrejevic S, Bukilica M, et al. Autoantibodies to mitotic apparatus: association with other autoantibodies and their clinical significance. J Clin Immunol 2006;26:438-46.

124. Mozo L, Gutierrez C, Gomez J. Antibodies to mitotic spindle apparatus: clinical significance of NuMA and HsEg5 autoantibodies. J Clin Immunol 2008;28:285-90.

125.Elnady BM, Kamal NM, Shaker RH, et al. Prevalence and clinical significance of nonorgan specific antibodies in patients with autoimmune thyroiditis as predictor markers for rheumatic diseases. Medicine (Baltimore) 2016;95:e4336.

126. Shiboski CH, Shiboski SC, Seror R, et al. 2016 American College of Rheumatology/European League Against Rheumatism classification criteria for primary Sjogren's syndrome: A consensus and data-driven methodology involving three international patient cohorts. Ann Rheum Dis 2017;76:9-16.

127.Petri M, Orbai AM, Alarcon GS, et al. Derivation and validation of the Systemic Lupus International Collaborating Clinics classification criteria for systemic lupus erythematosus. Arthritis Rheum 2012;64:2677-86.

128. Satoh M, Tanaka S, Chan EK. The uses and misuses of multiplex autoantibody assays in systemic autoimmune

doi: 10.21037/jlpm.2018.09.13

Cite this article as: Ceribelli A, Isailovic N, De Santis M, Generali E, Gorlino C, Palermo B, Selmi C. Clinical significance of rare serum autoantibodies in rheumatic diseases: a systematic literature review. J Lab Precis Med 2018;3:89. rheumatic diseases. Front Immunol 2015;6:181.

129. Conrad K, Andrade LE, Chan EK, et al. From autoantibody research to standardized diagnostic assays in the management of human diseases - report of the 12th Dresden Symposium on Autoantibodies. Lupus 2016;25:787-96.

130. Fujii T, Mimori T, Akizuki M. Detection of autoantibodies to nucleolar transcription factor NOR 90/hUBF in sera of patients with rheumatic diseases, by recombinant autoantigen-based assays. Arthritis Rheum 1996;39:1313-8.

131. Selmi C, Barin JG, Rose NR. Current trends in autoimmunity and the nervous system. J Autoimmun 2016;75:20-9.

132. Choi MY, Clarke AE, St Pierre Y, et al. The prevalence and determinants of anti-DFS70 autoantibodies in an international inception cohort of systemic lupus erythematosus patients. Lupus 2017;26:1051-9.

133. Gundín S, Irure-Ventura J, Asensio E, et al. Measurement of anti-DFS70 antibodies in patients with ANA-associated autoimmune rheumatic diseases suspicion is cost-effective. Auto Immun Highlights 2016;7:10.

134. Miyara M, Albesa R, Charuel JL, et al. Clinical phenotypes of patients with anti-DFS70/LEDGF antibodies in a routine ANA referral cohort. Clin Dev Immunol 2013;2013:703759.

135. Vázquez-Del Mercado M, Gomez-Banuelos E, NavarroHernandez RE, et al. Detection of autoantibodies to DSF70/LEDGFp75 in Mexican Hispanics using multiple complementary assay platforms. Auto Immun Highlights 2017;8:1. 